\title{
MUISTETTU JA UNOHDETTU MUSIIKKI
}

\section{Mitä muistitieto ja äänitemyyntitilastot kertovat 1980-luvun nuorten musiikkikulttuurista}

"Kaiken kaikkiaan 1980-luku taisi olla paras musiikkivuosikymmen!" (sKs KRA: NK72)

"Kaikki nuoret kuuntelivat musiikkia, se oli aivan keskeinen osa identiteettiä."

(SKS KRA: NK24)

1980-luku on viime vuosina muodostunut näkyväksi nostalgisoinnin kohteeksi populaarikulttuurin kentällä. Musiikin osalta tämä on ilmennyt muun muassa aikakautta käsittelevien radio- ja televisio-ohjelmien ja dokumenttielokuvien runsautena. Television puolelta osuvia esimerkkejä ovat muun muassa Yleisradiossa 2010-luvun alussa esitetyt rockdokumentit Paluu 80-luvulle ja RockSuomi. Aiheesta on myös ilmestynyt tietokirjoja (esim. Rantanen 2002; Sivonen 2009), minkä lisäksi monet fiktiiviset elokuvat ja televisiosarjat ovat keskittyneet 1980-luvun musiikkikulttuureihin. Teatterilavoilla tunnetuksi on tullut suomirockiin perustuva Vuonna 85 -musikaali. Populaarikulttuurille on laajemminkin tyypillistä eräänlainen vuosikymmenajattelu, jonka yhteydessä menneisiin vuo- 
sikymmeniin toistuvasti liitetään tiettyjä leimallisiksi miellettyjä piirteitä (Frith 1988 [1983]; van der Hoeven 2014: 316). Tässä artikkelissa luomme katsauksen siihen, miten 1980-luvulla eläneet nuoret itse muistelevat aikakauden musiikkia ja musiikin kuluttamista. Mitä 1980-luvun musiikista siis muistetaan?

Artikkeli perustuu Niin kasaria. Nuorisokulttuurit ja suomalaisen yhteiskunnan muutos 1980-luvulla -projektissa kerättyyn aineistoon. Projektissa tarkastellaan populaarimusiikkia 1980-luvun Suomessa erityisesti musiikkimakujen ja yleisöjen muutoksen sekä kuluttamisen ja faniuden näkökulmista. Musiikkikulttuurin ilmentymiä analysoidaan osana laajempia 1980-luvun yhteiskunnallisia ja kulttuurisia murroksia. Projektin erityisenä kiinnostuksen kohteena ovat nuorisokulttuurit, joiden havainnointiin populaarimusiikissa ja sen kulutuksessa tapahtuneet muutokset tarjoavat erinomaisen väylän.

1980-luku, "kasari", on 200o-luvulla alkanut kiinnostaa myös tutkijoita. Vuosikymmenen merkitys historiallisena ja suomalaisten elämäntapaa monilla tavoilla muuttaneena murroskohtana on vähitellen tunnistettu. 1980-luku merkitsi Suomessa muun muassa kylmän sodan päättymistä, kulutuskulttuurin nopeaa kasvua, kansainvälistymistä, voimakasta teknologista kehitystä sekä mediakulttuurin monipuolistumista ja vapautumista. Monet näistä muutoksista heijastuivat erityisen voimakkaina juuri nuorten elämään. 1980-lukua voidaankin pitää aikakautena, jolloin globalisoitumiseen, medioitumiseen ja kulutuskulttuuriin kytkeytyvä myöhäismoderni nuorisokulttuuri teki läpimurron. Suomessa ajanjaksolle sijoittuu valtava mediakentän muutos, jonka yksi ilmentymä oli Yleisradion hegemonia- ja monopoliaseman murtuminen. Tutkimustietoa ei silti ole vielä riittävästi saatavilla, mihin luonnollisesti on ainakin historiantutkimuksen näkökulmasta vaikuttanut ajallinen läheisyys (rock- ja popmusiikin, nuorisokulttuurien sekä yhteiskunnallisten muutosten välisistä yhteyksistä kansainvälisesti esimerkiksi Doggett 2007; Kallioniemi 2006; Poiger 1996; Ryback 1990; Zhuk 2010).

Populaarimusiikilla oli merkittävä rooli 1980-luvun nuorten arjessa. Aiemmassa tutkimuksessa ilmiötä on kyseisen aikakauden osalta tarkasteltu esimerkiksi rockin ja nuoruuden välisen suhteen (esim. Frith 1988 [1983]; Jokinen 2003) tai tiettyjen musiikkigenrejen ympärille rakentuneiden alakulttuurien näkökulmista (esim. Laing 2015 [1985]; Söderholm ym. 1987; Thornton 1995). Tässä artikkelissa tarkastelemme musiikkikulttuureja kulutuksen ja käytänteiden tasolla. 
Arjessa musiikki on tyypillisemmin lomittunut erilaisten toistuvien toimintojen kuten heräämisen, ruokailun, kotitöiden, läksyjen ja paikasta toiseen liikkumisen kanssa kuin vaikkapa rajautunut tiukasti alakulttuurisen aktiivisuuden keskiöön (Frith 1988 [1983]). Sijoitammekin 1980-luvun nuorten musiikkikulttuurit laajempiin (musiikin) kulutuksen ja nuorten arjen konteksteihin, kuten musiikin hankinnan mahdollisuuksiin ja musiikin kuuntelun paikkoihin. Liittämällä yksilölliset kokemukset rakenteellisiin ja yleisiin historiallisiin konteksteihin voidaan tutkimuksessa esiin nousevia ilmiöitä sekä ymmärtää että selittää.

Aineistona käytämme ensi sijassa Niin kasaria! / Så 8o-tal! -kirjoituskilpailussa kerättyjä yli sadan suomalaisen muistoja nuoruudesta ja musiikista 1980-luvulla. Muistitietoaineisto yhdistetään musiikin kulutusta koskevaan tilastoaineistoon eli tietoihin aikakauden kaupallisesti menestyneistä äänitteistä. Yhdessä tämä kvalitatiivinen ja kvantitatiivinen aineisto luovat aiempaa monimuotoisemman kuvan musiikin roolista nuorten arjessa. Muistitietoaineiston avulla voidaan myös tarkastella sitä, millaisia merkityksiä nuoruuden musiikilla on muistelijoilleen vuosikymmeniä myöhemmin (ks. esim. van der Hoeven 2014: 317). Tämän artikkelin tarkoituksena on näiden aineistojen pohjalta luoda mahdollisuuksia uusille näkökulmille ja lähestymistavoille 1980-luvun nuorison musiikkikulttuureihin.

Myyntilistojen ohella on mahdollista käyttää muitakin aineistoja, perustellusti esimerkiksi radioasemien soittolistoja, sillä 1980-luvun puolivälissä musiikin tarjonta laajeni merkittävästi paikallisradioiden läpimurron seurauksena (ks. esim. Kemppainen 2001; Kemppainen 2011: 230-238, 244-250, 261-262; Kurkela 2003: 615, 617-618; Salokangas 1996: 338-339, 367; Töykkälä \& Uusitupa 1987: 43-45; Uimonen 2011). Radiotoiminnassa tapahtuneet muutokset asettavat tutkimukselle kuitenkin sekä lähdeaineiston että analyysin osalta omat haasteensa, jotka eivät sovi tämän artikkelin lähestymistapaan ja laajuuteen.

Kirjoittajien osin erilaiset kokemustaustat täydentävät toisiaan ja toimivat lisäksi menetelmällisenä apuvälineenä. Kirjoittajista Tanja Välisalo on ollut tutkittavana aikakautena lapsi ja on tutkimusaiheen kannalta lähes "ulkopuolinen", ja näin ollen hän osaa esittää aineistoille kysymyksiä tuoreista näkökulmista. Petri Karonen on puolestaan elänyt kukkeimman nuoruutensa juuri tarkastelujaksolla, mikä toisaalta auttaa ylittämään muistitietoaineiston tulkintahaasteita ja tarjoaa tutkijalle kykyjä suhteuttaa erilaisia havaintoja isompiin kokonaisuuksiin. Toi- 
saalta tämä kokemustausta asettaa tutkijan itsereflektiolle omat vaatimuksensa, sillä aikalaisuus voi myös sokeuttaa ja johtaa tiettyjen tulkintojen korostumiseen pätevämpien tulkintojen kustannuksella.

\section{Menetelmät ja tutkimusaineistot}

Musiikkikulttuurien historiaan kohdistuva tutkimus sekä antaa tilaisuuden käyttää että suorastaan edellyttää monimenetelmäistä lähestymistapaa, jossa yhdistetään erilaisia tutkimusaineistoja ja analyysimenetelmiä. Tämän tutkimuksen aineistona olevia muistelukirjoituksia lähestymme muistitietotutkimuksen metodein. Muistitietotutkimus on tyypillisesti jaettu kahteen pääsuuntaukseen, selittävään ja ymmärtävään. Käytännössä molemmat lähestymistavat ovat kuitenkin usein läsnä samassa tutkimuksessa (Fingerroos \& Haanpää 2006: 38-40). Tässä artikkelissa tarkastelemme muisteluaineistoa kuvaajana ja selittäjänä niille 1980-luvun käytänteille, jotka liittyvät musiikin kulutukseen nuorison keskuudessa. Samalla pyrimme myös ymmärtämään niitä merkityksiä, joita muistelijat antavat musiikille ja omille muistoilleen.

Vaikka muistitieto kertoo "vähemmän menneisyyden tosista tapahtumista kuin siitä, mikä näiden tapahtumien merkitys oli tai on muisteluhetkellä" (Fingerroos \& Haanpää 2006: 33), muistitietoaineiston tarkastelussa lähdemme siitä oletuksesta, että muistelijat ovat todella kuunnelleet niitä laulajia ja yhtyeitä, joita he kirjoituksissaan mainitsevat ja että heidän kuvauksensa musiikin kuuntelun materiaalisista ja sosiaalisista konteksteista kuvastavat todellisia tapahtumia. Kirjoitettujen muistojen ei voi olettaa täysin kattavan yksittäisen muistelijan musiikin kulutusta, eikä yksityiskohtien tarkkuudesta ole takeita. Tarkastelemme muistojen faktuaalista tasoa kuitenkin ennen kaikkea muisteluaineiston kokonaisuuden osana, jolloin kiinnostuksen kohteenamme ei olekaan yksityiskohtien tai yksittäisen kirjoittajan muistojen paikkansapitävyys, vaan kirjoitusten muodostama kokonaiskuva. Merkittävässä roolissa ovat musiikin saamat merkitykset nykyhetkessä. Muisteltavien tapahtumien aiempi toistuva kertominen, toisten ihmisten muistot samoista tapahtumista ja aikakaudesta sekä median tuottamat kuvaukset vaikuttavat kaikki osaltaan siihen, mitä muistetaan ja mitä kerrotaan, samoin odotukset yleisöstä ja erilaiset tekstuaaliset repertuaarit, eli erilaiset ker- 
ronnan tekniikat, joita muistelijalla on käytössään (Abrams 2010: 79; Pöysä 2015; 24; Wertsch 2002: 6, 8). Kiinnitämmekin huomion juuri siihen, mikä 1980-luvun musiikkikulttuurissa on merkityksellistä muistelijoille muisteluhetkellä.

Ymmärtävälle muistitietotutkimukselle on hahmoteltu myös oma alalajinsa, kriittinen tai emansipatorinen suuntaus (Fingerroos \& Haanpää 2006, 40; Pöysä 2006), jonka tavoitteena on muokata tulkintaa menneisyydestä ja joka osaltaan korostaa sitä, että tutkimuksessa muistitietotutkimuksen eri tasot voivat olla läsnä myös yhtä aikaa tai limittäin. Emansipatorinen ulottuvuus on läsnä tässäkin artikkelissa, sillä pyrimme monipuolistamaan kuvaa 1980-luvusta, joka on usein nähty edeltäviin ja seuraaviin vuosikymmeniin nähden "huonomman" musiikin sekä kaupallisen ja epäpoliittisen musiikkikulttuurien valtakautena. Mediassa näkyvyyttä on saanut muun muassa tutkimustulos, jossa Yhdysvalloissa 1980-luvun soitetuinta ja myydyintä musiikkia luonnehditaan musiikillisten piirteiden analyysin perusteella poikkeuksellisen yksitoikkoiseksi (Mauch et al. 2015: 5). Toisaalta tavoitteemme on nostaa esille niin sanottujen tavallisten nuorten arkea ja kokemuksia ideologisten tai poliittisten alakulttuurien rinnalle.

Musiikkimuistoja kerättiin kirjoituskilpailulla, joka on Suomessa yksi vakiintuneista tavoista hankkia muistitietoaineistoa. Kilpailukutsu laadittiin mahdollisimman laajasti nuorten musiikkimaisemaa koskevan muisteluaineiston kartuttamiseksi: kirjoittajia pyydettiin muistelemaan esimerkiksi sitä, mitä musiikkia he kuuntelivat, missä ja kenen kanssa, miten uuteen musiikkiin tutustuttiin, miten musiikkikulttuurit näkyivät muodissa, tyylissä tai harrastuksissa ja millaisia merkityksiä musiikkiin liitettiin. Käytämme tässä yhteydessä musiikkimaiseman käsitettä kuvaamaan 1980-luvun Suomessa saatavilla ollutta ja merkitykselliseksi koettua musiikkia eri konteksteissaan. Musiikkimaiseman käsite eroaa siten esimerkiksi musiikintutkimuksessa yleisestä äänimaiseman käsitteestä (esim. Ampuja ym. 2005: 12-13; Ampuja \& Peltomaa 2014:, 356; Uimonen ym. 2017).

Tällaiset tiettyihin teemoihin keskittyvät kirjoituskutsut tuottavat sisällöllisesti ja kielellisesti kirjavia tekstejä. Näiden tekstien rikkautena ja samalla yhtenä metodisena haasteena on niiden monenkeskisyys (Pöysä 2015: 19-20, 23-24): muistelijat kirjoittavat lukuisista eri kulttuurisista, sosiaalisista ja taloudellisista konteksteista käsin ja edustavat usein eri sukupolvia. Muistelun kohteena ei siis ole yksi kaikille muistelijoille yhteinen musiikkikulttuuri, vaan muistot sijoittuvat hyvinkin erilaisiin nuoriso- ja musiikkikulttuurisiin konteksteihin. Pidämme 
tätä moniäänisyyttä paremminkin rikkautena kuin ongelmana, sillä se tuo esille erilaisia musiikin kulutukseen liittyviä ilmiöitä ja käytänteitä ja siten laajentaa käsitystä tutkimuksen kohteena olevasta aikakaudesta.

Muistitietoaineistoa 1980-luvun nuorten musiikkikulttuureista kerättiin yhteistyössä Suomalaisen Kirjallisuuden Seuran (sKs) ja Svenska litteratursällskapet i Finlandin (sLs) kanssa 1.2.-30.11.2015. Musiikkiin liittyen on aiemminkin järjestetty muistitietokeruita, kuten Musiikin merkitys (1994), Elämysten jäljillä (1995), Kasettimuistot talteen (2010) ja Fanimuistot talteen (2011-2012), mutta Niin kasaria! / Så 8o-tal! -keruu haluttiin kohdentaa juuri 1980-luvulla nuoruuttaan eläneille muistelijoille. Tietoa kyselystä levitettiin mediassa, keruun omien verkkosivujen ja sosiaalisen median kanavien välityksellä sekä arkistojen vastaajalistojen kautta. Keruun nimestä huokui nostalginen suhtautuminen 1980-lukuun, mitä myös hankkeeseen kohdistunut mediajulkisuus osaltaan korosti.

Suomenkielisiä vastauksia kertyi sKs:n keruun kautta 92 ja ruotsinkielisiä tekstejä sLs:n kautta 15. Kirjoitettujen muistelmien lisäksi vastaajat lähettivät valokuvamateriaalia sekä listoja henkilökohtaisen musiikkikokoelmansa sisältämistä äänitteistä. Äänitelistoja emme kuitenkaan hyödynnä tässä tutkimuksessa. Niitä oli vain parissa vastauksessa, ja aikalaislähteinä ne poikkeavat luonteeltaan muistitietoaineistosta eivätkä samalla tavalla kuvasta sitä, mitä musiikista muistetaan myöhemmin. Muistelukirjoituksiin jotkut kirjoittajat sisällyttivät myös päiväkirjaotteita, jotka puolestaan otimme mukaan analyysiin, sillä näihin on muisteluteksteissä liitetty tulkitsevaa ja kontekstoivaa kerrontaa.

Muistelijoita pyydettiin kertomaan, millä paikkakunnalla he asuivat kuvaamiensa tapahtumien aikaan. Yhteensä 62 vastaajaa mainitsi paikkakunnan. Vastauksia tuli ympäri maata, mutta selvästi eniten muisteltiin nuoruutta Uudellamaalla ja Varsinais-Suomessa. Vastaajista 78 kertoi syntymävuotensa. Heistä 61 oli syntynyt vuosien 1962-1971 välillä, ja vastaajien syntymävuosien mediaani osui vuoteen 1968 . Vastaajista 56 prosenttia oli naisia ja 44 prosenttia miehiä.

Tutkimuksemme toisen aineiston muodostavat vuosien 1980-1989 suomalaiset äänitemyyntitilastot, jotka on koostettu Timo Pennasen huolellisesti ja lähdekriittisesti punnitusta, kuukausittain etenevästä Top 20 -albumilistauksesta (Pennanen 2006, kokoamisperusteista ja lähdekritiikistä erityisesti 8-11; singlelistoista esimerkiksi Lassila 1990, liite 6). Nämä myyntilistat paljastavat paitsi ilmeisimmän sisältönsä, eniten myydyt äänitteet, myös sen, keiden artistien nimet 
toistuivat julkisuudessa, kun näitä listoja julkaistiin muun muassa nuortenlehdissä ja tärkeimmissä yleisissä viikkolehdissä kuten Avussa ja Seurassa. Äänitemyyntilistot eivät toki kerro yksin nuorten musiikin kulutuksesta, sillä äänitteitä ostivat myös aikuiset, mutta juuri vertailu muistitietoaineistoon antaa osaltaan mahdollisuuden havaita erilaisten rinnakkaisten musiikkikulttuurien läsnäolo myyntilistoilla.

Koska muistelukirjoitukset ja äänitemyyntitilastot poikkeavat tutkimusaineistoina monin tavoin toisistaan, niiden analyysiin ja tulkintaan on tarpeen soveltaa jossain määrin erilaisia menetelmiä. Laadullisen analyysin lisäksi teimme muistitietoaineistosta kuvailevaa tilastollista analyysia. Tämä tapahtui koodaamalla aineisto laadullisen aineiston käsittelyyn tarkoitetulla Atlas.ti-analyysiohjelmalla. Kirjoituksista valittiin lainauksia, joille annettiin sisältöä kuvaavia koodeja, esimerkiksi muistelijan mainitsemat laulajat ja yhtyeet, musiikintoistolaitteet, konsertit ja musiikkifestivaalit. Tämä antoi edellytykset laskea eri koodien esiintymismääriä. Vaikka aineistossa oli mukana myös joitakin mainintoja musiikista, josta muistelijat nimenomaisesti eivät pitäneet, nämä maininnat on jätetty tämän tutkimuksen ulkopuolelle. Määrällisestä käsittelystä huolimatta muistitietoaineistoa ei kuitenkaan ole kerätty tilastollisen otannan perusteella. Aineisto ei siis ole siinä mielessä edustava, että sen perusteella olisi mahdollista tehdä päätelmiä kaikkien 1980-luvulla nuoruuttaan eläneiden suomalaisten kokemuksista, vaikka aineiston analyysi antaakin viitteitä myös laajemmista kulttuurisista ilmiöistä. Muistelukirjoitusten ja äänitemyyntilastojen vertailu ei siis ole suoraviivaista tilastollista analyysia, vaan vertailemme molemmista aineistoista muodostettuja kuvailevia tilastoja laajempaa kontekstia vasten.

\section{Nuorten muistelema musiikkimaisema}

Mitä musiikkia nuoruutta 1980-luvulla muistelevat sitten kertovat kuunnelleensa? Lähes kaikki vastaajat mainitsevat musiikkiesiintyjiä nimeltä, ja muisteluaineistossa nimetäänkin peräti 698 yhtyettä tai laulajaa. Alle puolet näistä (275) esiintyy vähintään kahdessa eri vastauksessa, joten merkittävä osa (61 \%) artisteista mainitaan vain yhden vastaajan muisteluissa. Nämä luvut kertovat yhtäältä muistelijoille merkityksellisen musiikin laajasta kirjosta ja toisaalta siitä, 
että koko muistelijajoukolle yhteisesti merkittäviä esiintyjiä oli suhteessa varsin vähän: kymmenen tai sitä useamman muistelukirjoituksen joukkoon pääsi vain 29 esiintyjää. Yhdessä muistelukirjoituksessa nostettiin esille tyypillisimmillään (mediaani) 10 artistia. Musiikin esittäjiä kuvaillaan aineistossa monin tavoin: osana luetteloa mieleen jääneistä esiintyjistä, mainintana vaikkapa ensimmäisestä konserttikokemuksesta tai pitkinä kuvauksina kyseisen yhtyeen tai laulajan musiikista ja sen roolista vastaajan elämässä. Esiintyjiä voidaan vielä kategorisoida toteamalla, että heistä 256 oli laulajia ja 442 yhtyeitä. Esiintyjien enemmistö, 545, oli ulkomaisia ja loput 153 suomalaisia.

Muistelluista esiintyjistä Dingo mainitaan useammin kuin yksikään toinen artisti (ks. taulukko 1). Yhtyeestä myös kirjoitetaan useissa muisteluteksteissä selvästi runsassanaisemmin kuin muista artisteista. Niin ikään yhtyeen hajoaminen muistetaan mainita, kuten tässä erään kirjoittajan kuvauksessa: "Olin Suomipopin suhteen kaikkiruokainen, mutta toista Dingoa ei tullut. Dingon hajotessa [1986] katsoin iltauutisia ja itkin - suuri oli suru kun rakas yhtye, jonka tahtiin olin pari vuotta hengittänyt, loppui" (SKS KRA: NK66). Dingon hajoamista on henkilökohtaisten muistojen lisäksi sittemmin korostettu muun muassa kierrättämällä tapahtumasta kertonutta televisiouutista lukuisissa televisio-ohjelmissa. Dingo-ilmiö erottuukin aikakaudelta kokonaisvaltaisena kulttuurisena ilmiönä, jonka vaikutus näkyy vielä vuosikymmeniä myöhemmin. Muistelmissa nimetään poikkeuksellisen paljon Dingon levyjä ja kappaleita, vaikka muuten yksittäisiä musiikkialbumeita ja kappaleita mainitaan aineistossa vain vähän. Valtaosa useimmin mainituista musiikkiesiintyjistä on ollut aktiivisia pitkään 1980-luvun jälkeen, ja osa on sitä edelleen, mutta vuosikymmentä koskevissa musiikkimuistoissa vastaajia selvimmin yhdistävä artisti on yhtye, joka hajosi jo vuonna 1986. Dingon asema muistitietoaineistossa ja 1980-luvun suomalaisessa musiikkimaisemassa on poikkeuksellinen.

Musiikkigenrejen osalta eniten mainintoja saaneet kotimaiset yhtyeet ja laulajat edustavat lähes kaikki suomirockia, tai ainakin suomenkielistä kitararockia. Vähintään kymmenessä eri kirjoituksessa mainintoja saaneita kotimaisia esiintyjiä on vain kahdeksan, ja niistä ainoastaan Hanoi Rocks esitti musiikkiaan englannin kielellä. Kaikkien näiden artistien ura alkoi jo 1970-luvun lopussa tai viimeistään 1980-luvun alussa. Ainoa poikkeus tästä aikarajauksesta on Juice Leskinen, jonka musiikki oli ilmestynyt myyntilistojen kärkisijoille jo 1970-luvun 
puolivälissä. Muistelluimpien kotimaisten artistien listan perusteella 1980-luvun voi kenties nähdä ikään kuin alkaneen jo 1970-luvun lopulla (ks. ilmiöstä, aikakaudesta sekä keskeisistä artisteista erityisesti Kurkela 2003: 555-602; ks. myös Gronow ym. 2004).

\begin{tabular}{|c|c|c|c|c|}
\hline Artisti & SKS & SLS & Vastaajat yht. & Artistin aktiiviset vuodet \\
\hline Dingo & 29 & 5 & 34 & 1982, 1986, 1993-1994, 1998-2002, 2004- \\
\hline Eppu Normaali & 26 & 3 & 29 & $1976-$ \\
\hline Pelle Miljoona** & 24 & 2 & 26 & 1977- \\
\hline Popeda & 19 & 2 & 21 & $1977-$ \\
\hline Hanoi Rocks & 18 & 2 & 20 & 1979-1985, 2001-2009 \\
\hline Juice Leskinen** & 18 & 1 & 19 & 1973-2006 \\
\hline Yö & 16 & 0 & 16 & $1981-$ \\
\hline Hassisen kone & 15 & 0 & 15 & 1979-1982, 2001 \\
\hline J. Karjalainen** & 8 & 1 & 9 & 1981- \\
\hline Sielun veljet & 9 & 0 & 9 & 1982-1992, 2010, 2011 \\
\hline
\end{tabular}

Taulukko 1. Muisteluaineistossa useimmin mainitut suomalaiset artistit.

Kirjoituksissa tuodaan esille enemmän ulkomaisia kuin kotimaisia esiintyjiä. Kansainvälisten artistien maininnat ovat myös jakautuneet tasaisemmin eri artisteille verrattuna yhteisiin suomalaisiin suosikkeihin - vähintään kymmeneen mainintaan yltää 21 ulkomaista esiintyjää. Yhdysvallat ja Iso-Britannia hallitsevat nimilistaa, mutta joukossa on artisteja myös eri puolilta Eurooppaa. Suomalaisiin artisteihin verrattuna ulkomaiset edustavat selvästi suurempaa genrevalikoimaa - mukana on rockin monien alalajien lisäksi popmusiikkia eri muodoissaan, muun muassa laulaja Madonna ja syntetisaattoreita hyödyntänyt saksalaisyhtye Modern Talking (ks. taulukko 2). Kiinnostavaa on, että naispuolisia muusikoita on vain muistelluimpien kansainvälisten artistien joukossa. Suomalaisartistien listalta he puuttuvat lähes täysin. Tätä kenties selittää suomalaisen artistilistan 
rockpainotteisuus: vaikka naispuoliset muusikot tulivat osaksi rockkulttuuria 1980-luvulla, heidän osuutensa oli vielä hyvin pieni (Lähteenmaa 1992: 216; Skaniakos 2010: 128; yleisesti suomalaisista naisartisteista 1980-luvulla Kurkela 2003, 60o-601; myös Lassila 1990). Muistitietoaineiston harvat maininnat yksittäisistä musiikkivideoista liittyvät tyypillisesti ulkomaisiin esiintyjiin, erityisesti Michael Jacksoniin, David Bowieen ja Madonnaan.

$\begin{array}{lllll}\text { Artisti } & \text { SKS } & \text { SLS } & \text { Vastaajat yht. } & \text { Artistin aktiiviset vuodet } \\ \text { Madonna } & 23 & 5 & 28 & 1979- \\ \text { Duran Duran } & 18 & 6 & 24 & 1982- \\ \text { U2 } & 16 & 5 & 21 & 1980- \\ \text { Michael Jackson } & 15 & 3 & 18 & 1972-2009 \\ \text { KISS } & 5 & 9 & 14 & 1974- \\ \text { David Bowie } & 10 & 3 & 13 & 1966-2016 \\ \text { Carola Häggkvist } & 4 & 9 & 13 & 1983- \\ \text { Bruce Springsteen } & 9 & 4 & 13 & 1973- \\ \text { Europe } & 6 & 6 & 12 & 1983-1992,2003- \\ \text { Modern Talking } & 7 & 5 & 12 & 1985-1987,1998-2003 \\ \text { The Beatles } & 11 & 1 & 12 & 1961-1970\end{array}$

Taulukko 2. Muisteluaineistossa useimmin mainitut kansainväliset artistit.

Vaikka muistitietoaineisto ei ole edustava siinä mielessä, että sen perusteella voisi tehdä eri demografisia ryhmiä koskevia yleistyksiä, on kuitenkin huomionarvoista, että ruotsiksi vastanneiden, todennäköisesti siis äidinkieleltään ruotsinkielisten tai kaksikielisten vastaajien muistoissa suomalaiset yhtyeet ovat marginaalissa (5\% mainituista artisteista), kun taas suomenkielisten vastaajien teksteissä heitä on reilu kolmannes (36\%). Ruotsinkieliset vastaajat muistelevat lisäksi erityisen paljon ruotsalaisia artisteja, joista mainitaan niin englanniksi laulaneet Roxette, Abba ja Europe kuin pääosin ruotsiksi laulaneet Carola Häggkvist, Herreys ja Gyllene Tider (katso taulukko 3). Erojen taustalla vaikuttaakin ruotsinkielisten vastaajien erilainen mediamaisema. Ruotsin median vaikutus näkyy 
varsinkin länsirannikolla ja Pohjanmaalla 1980-luvulla asuneiden ruotsinkielisten vastauksissa. Kirjoittajat mainitsevat musiikin lähteeksi muun muassa Tracklistan-ohjelman, jota Ruotsin radio lähetti kanavalla $\mathrm{P}_{3}$ vuodesta 1984 alkaen.

Roxette-yhtye on erityisen kuvaava esimerkki suomenkielisten ja ruotsinkielisten musiikkimuistojen eroista. Roxetten vuonna 1986 julkaistu ensimmäinen single ja albumi menestyivät erittäin hyvin Ruotsissa, mutta yhtyeen suosio ulottui Suomeen ja muualle Eurooppaan vasta pari vuotta myöhemmin. Suomessa yhtye todennäköisesti onkin leimallisemmin osa 1990-luvun musiikkimaisemaa. Suomenkielisissä muisteluissa Roxette ei nouse esiin, kun taas suuressa osassa ruotsinkielisiä vastauksia yhtye huomioidaan. Lisäksi samat ruotsinkieliset vastaajat mainitsevat Roxettea edeltäneen Gyllene Tider -yhtyeen, jota puolestaan suomenkieliset muistelijat eivät noteeraa ollenkaan. Molemmissa yhtyeissä oli perustajajäsenenä kitaristi Per Gessle, joten onkin todennäköistä, että osa Gyllene Tideriä kuunnelleista hakeutui juuri hänen mukanaan Roxetten musiikin äärelle.

$\begin{array}{llll}\text { Artisti } & \text { SKS } & \text { Artisti } & \text { SKS } \\ \text { Dingo } & 29 & \text { Carola Häggkvist } & 9 \\ \text { Eppu Normaali } & 26 & \text { Gyllene Tider } & 8 \\ \text { Madonna } & 23 & \text { Roxette } & 7 \\ \text { Pelle Miljoona } & 24 & \text { Duran Duran } & 6 \\ \text { Madonna } & 23 & \text { Europe } & 6 \\ \text { Popeda } & 19 & \text { Wham } & 6 \\ \text { Duran Duran } & 18 & \text { Dingo } & 5 \\ \text { Hanoi Rocks } & 18 & \text { Madonna } & 5 \\ \text { Juice Leskinen } & 18 & \text { U2 } & 5 \\ \text { U2 } & 16 & \text { KISS } & 5 \\ \text { Yö } & 16 & \text { Modern Talking } & 5 \\ \text { Hassisen kone } & 15 & \text { Alphaville } & 5 \\ \text { Michael Jackson } & 14 & \text { Herreys } & 5 \\ & & & 5\end{array}$

Taulukko 3. Mainituimmat artistit sKs:n suomenkielisessä ja sLs:n ruotsinkielisessä aineistossa. 


\section{Muistellun ja myydyn musiikin vertailua}

Musiikintoistolaitteet olivat 1980-luvun alkuun tultaessa yleistyneet - esimerkiksi kasettisoittimen kattavuus kotitalouksissa oli 145 prosenttia, joten monessa taloudessa oli siis vähintään kaksi soitinta (Muikku 2001: 267; Poikolainen 2015: 76). Kasettisoittimet mahdollistivat nuorille musiikin kuuntelun oman huoneen rauhassa tai jopa kodin ulkopuolella (Uimonen 2012: 104, 106). Sekä äänikasettien että tallentamattomien äänikasettien myynti olikin huipussaan juuri 1980-luvulla (Kilpiö ym. 2015: 37, 109). Musiikin nostalgisointi julkisuudessa liittyykin usein äänitteiden myyntiin. Tyypillisesti artistien ja musiikinlajien suosiota on perusteltu sillä, miten hyvin äänitteet ovat käyneet kaupaksi (ks. esim. listakirjat Nyman 2005 ja Sirén 2017).

Äänitemyynti ei ollut sama asia kuin äänitteiden leviäminen. Erityinen vaikutus musiikkimaisemaan oli C-kasettien kotinauhoittamisella. Kuten jo aiemmassa tutkimuksessa on todettu, kasetti jossain määrin "vapautti" nuoret Yleisradion ja levy-yhtiöiden kaupallisesta ja kulttuurisesta vallasta, kun radiomusiikin ja äänilevyjen äänittäminen kasetille mahdollisti musiikin omaehtoisen koostamisen ja jakamisen (Kilpiö ym. 2015: 9, 34). Vuonna 2010 toteutetun Kasettimuistotkyselyn vastaajista 92 prosenttia tallensi kasetille ensisijaisesti radiosta, suuri osa myös äänilevyiltä (78\%) tai kirjaston kokoelmista (47\%) (Uimonen 2012: 106). Vastaajat korostivat kasetin vaikutusta musiikin kuuntelun monipuolistajana (Uimonen 2012: 102). Samalla tavalla Niin kasaria! -kirjoituskeruussa 1980-lukua muistelleet vastaajat mainitsevat toistuvasti C-kaseteille nauhoittamisen - selvästi useammin kuin levyjen tai kasettien ostamisen.

Niin kasaria! -aineistossa muisteltujen artistien määrä ja musiikkimaun suuri hajonta kertovat osaltaan musiikin tarjonnan moninaisuudesta ja saatavuudesta. Vertailemmekin seuraavaksi muistitietoaineistoa ja äänitemyyntitilastoja saadaksemme aiempaa tarkemman kuvan siitä, miten ja missä määrin nämä eroavat toisistaan. Muistelukirjoitusten ja myyntilistojen tarjoaman tiedon selkeä ero on se, että muistelijat mainitsevat kuuntelemiaan yhtyeitä ja laulajia, mutta yksittäisiin kappaleisiin tai albumeihin ei juurikaan viitata. Puolet vastaajista (53; 50 \%) ei nimeä yhtään kappaletta, ja vielä suurempi osa $(67 ; 63 \%)$ sivuuttaa albumit. Yksittäisiä albumeja nostettiin esiin yhteensä 143, kaikkiaan 101 artistilta - eli vain murto-osalta kaikista aineistossa mainituista artisteista. Nimetyistä albu- 
meista kolmannes (51) nousi aikakauden Top 20 -myyntilistoille. Joukossa on paljon sellaisia levytyksiä, jotka eivät yltäneet myyntilistoille, ja lisäksi sellaisia äänitteitä, jotka on julkaistu jo ennen 1980-lukua. Näyttäisi siltä, että aikakauden menestystuotteita tarkastelemalla 1980-luvun musiikkimaisema ei avaudu riittävästi. Vesa Kurkela $(2003,597)$ toteaa yksistään 1980-luvun suomirockista, että myyntilistojen perusteella sen "kuva näyttääkin huomattavasti yksioikoisemmalta kuin nimikelistat." Muistelukirjoitusten ja myyntilistojen vertailussa on siis keskityttävä ensisijaisesti artisteihin.

Ensimmäinen selkeä havainto muistitietoaineiston ja äänitemyyntitilastojen musiikkiesiintyjien eroista on, että muistitietoaineistossa mainitaan selvästi enemmän artisteja (698) kuin myydyimpien levyjen Top 20 -listoille mahtuu (448). Kirjoittajat muistelevat siis paljon artisteja, joiden julkaisut eivät milloinkaan yltäneet myydyimpien äänitteiden joukkoon. Tämä tukee aiemman tutkimuksen muodostamaa kuvaa nuorten musiikkimaun monipuolistumisesta. Mukana on sekä pieniä paikallisia yhtyeitä että vähemmän tunnettuja tai tiettyyn alakulttuuriin kuuluneita kotimaisia ja ulkomaisia yhtyeitä. Joukossa on myös artisteja, joiden suurin myyntimenestys oli 1980-luvulla ainakin toistaiseksi mennyttä tai vasta tulossa.

Kun tarkastellaan muisteltujen artistien kansallisuutta, niin heistä suomalaisia on 22 prosenttia. Myydyimpien äänilevyjen listoilla suomalaisartistien osuus puolestaan on 26 prosenttia. Ulkomaisia artisteja muisteluaineistossa esiintyy 78 prosenttia, siis hiukan enemmän kuin myydyimpien levyjen listoilla (74 \%). Vaikka näiden kahden aineiston luvut eivät ole suoraan vertailukelpoisia, niin ne näyttävät vahvistavan toisiaan - ulkomaiset artistit korostuvat sekä muisteluaineistossa että myyntitilastoissa. Musiikkimaun kansainvälistyminen näkyy myös äänitemyyntitilastojen muutoksissa - 1980-luvun edetessä kotimaisten artistien osuus myyntilistoilla pieneni ja myydyimmät artistit olivat yhä useammin samoja kuin esimerkiksi Iso-Britannian myyntilistoilla (ks. taulukko 4). 


$\begin{array}{llll}\text { Kk/Vuosi } & \begin{array}{l}\text { Suomen Top 20 - } \\ \text { lista, joista } \\ \text { kotimaisia artisteja }\end{array} & \begin{array}{l}\text { Suomen Top 20 - } \\ \text { listan ulkomaiset } \\ \text { artistit, jotka olivat } \\ \text { yhtä aikaa Iso- } \\ \text { Britannian Top 20 - listalla }\end{array} & \begin{array}{l}\text { Vuonna 2017 edelleen } \\ \text { aktiivisia artisteja } \\ \text { (sekä kotimaiset että } \\ \text { ulkomaiset otettu } \\ \text { huomioon) }\end{array} \\ 7 / 1980 & 12 & 1 & 13 \\ 7 / 1985 & 6 & 5 & 13 \\ 7 / 1989 & 4 & 7 & 9 \\ \text { Yht. } & 22 & 13 & 35 \% \\ \text { Yht. osuus kaikista } & 37 \% & 22 \% & 58 \%\end{array}$

Taulukko 4. Suomen Top 20 -myyntilistan artistien vertailu Iso-Britannian myyntilistalla samaan aikaan olleisiin artisteihin sekä artistien mahdollinen aktiivisuus vuonna 2017.

Eniten myyneitä kotimaisia artisteja muistellaan ahkerasti. Myyntilistoilla parhaiten menestyneet Eppu Normaali ja Juice Leskinen ovat muistitietoaineistonkin eniten mainintoja saaneiden artistien joukossa (ks. taulukko 5). Suomalaisista Vesa-Matti Loiri on ainoa artisti, joka esiintyy tiuhaan myyntilistoilla mutta ei ollenkaan muistelukirjoituksissa. Samoin monet muut kotimaiset menestysnimet kuten Hector, Pave Maijanen ja Sleepy Sleepers saavat muistelijoilta vain yksittäisiä mainintoja. Merkille pantavaa onkin, että muistelluimmat suomalaiset artistit ovat kaikki aloittaneet uransa 1970-luvun lopulla tai 1980-luvun alussa, kun taas äänitemyynnissä menestyneet mutta muistelijoiden ohittamat artistit olivat aloittaneet uransa selvästi aiemmin ja olivat siis oikeastaan osa edellisen sukupolven nuoruutta (vrt. Jokinen 2003: 55 sekä Kurkela 2003: 569, 592, 594; Kallioniemi ym. 2016: 407-413). Myös muistot live-esiintymisistä keskittyvät muutamiin sellaisiin suomalaisnimiin, jotka ovat näkyvästi esillä sekä myyntilistoilla että muisteluaineistossa: erityisesti muistellaan Popedan, Eppu Normaalin, Dingon ja Juice Leskisen keikkoja (ks. myös Kurkela 2003, 596-598). 


$\begin{array}{lcc}\text { Artisti } & \text { Top 20 -sijoituksia } & \text { Vastaajat } \\ \text { Eppu Normaali } & 47 & 29 \\ \text { J. Karjalainen \& Mustat lasit } & 26 & 22^{*} \\ \text { Dingo } & 20 & 7 \\ \text { Vesa-Matti Loiri } & 20 & 0 \\ \text { Popeda } & 19 & 34 \\ \text { Sleepy Sleepers } & 18 & 21 \\ \text { Hector } & 17 & 3 \\ \text { Juice Leskinen Grand Slam } & 17 & 1 \\ \text { Pave Maijanen } & 16 & 3 \\ \text { Pelle Miljoona Oy } & 16 & 6 \\ \text { Tuomari Nurmio } & 16 & 6 \\ \text { *Aineistossa mainitaan sekä J. Karjalainen ja Mustat lasit että pelkästään J. Karjalainen. Tässä luvussa on huomioitu molem- } \\ \text { mat. }\end{array}$

Taulukko 5. Eniten albumeja myyneet suomalaiset artistit Suomessa vuosina 1980-1989 sekä artistin muisteluaineistossa maininneet vastaajat.

Myös eniten myyneet kansainväliset tähdet ovat jääneet hyvin Suomessa 1980-luvulla eläneiden nuorten mieliin. Ulkomaisten artistien myydyimpien ja muistelluimpien listoissa on kuitenkin suomalaisartisteihin verrattuna paljon vähemmän päällekkäisyyttä - vain Madonna ja Michael Jackson ovat sekä äänitemyyntilistoilla menestyneitä että lukuisten muistojen kohteena (katso taulukko 6). Ulkomaisten artistien osalta muistelijoiden musiikkimaku siis hajautui laajemmalle. Yhtenä syynä epäilemättä on se, että ulkomaisen musiikin tarjonta oli huomattavasti suurempi kuin suomalaisen musiikin.

Myyntilistoilla menestyneistä artisteista laulajat Diana Ross (s. 1944) ja Barbra Streisand (s. 1942) jäivät muistitietoaineistossa lähes ilman mainintoja. He olivat aloittaneet uransa aiemmin kuin monet muut lista-artistit, eikä kumpikaan edusta leimallisesti 1980-luvun nuorisomusiikkia. Sen sijaan muistelluimpien ulkomaisten artistien joukossa on samoihin aikoihin Rossin ja Streisandin kanssa uransa aloittanut David Bowie, jonka suosion ensimmäinen huippu oli sijoittunut 1970-luvun alkuun. 
Ulkomaalaisia esiintyjiä koskevissa muisteluissa nousee esiin yksi merkittävä poikkeus. Brittiyhtye The Beatles mainitaan useissa kirjoituksissa, vaikka se ei juurikaan esiinny myyntilistojen kärjessä: vain yksi kokoelma-albumi päätyi myyntilistoille kahdeksi kuukaudeksi vuoden 1980 joulusesongin aikaan. Leimallisesti 1960-lukuun liitetyn Beatlesin vankka kulttuurinen asema näkyy siis myös myöhempien vuosikymmenien muistelussa. Muistelijat kertovat saaneensa Beatlesin perintönä vanhemmiltaan tai tutustuneensa yhtyeeseen median kautta, kuten eräs vastaaja kuvailee: "Kaikki oli Rockradion syytä. Rockradio aloitti kesällä 1980 ja esitti heti alkuun kuunnelmasarjan 'Olipa kerran Beatles'”' (sKs KRA: NK81).

$\begin{array}{lll}\text { Artisti } & \text { Top 20 -sijoituksia } & \text { Vastaajat } \\ \text { Dire Straits } & 30 & 11 \\ \text { Bruce Springsteen } & 24 & 13 \\ \text { Michael Jackson } & 23 & 18 \\ \text { Barbra Streisand } & 22 & 1 \\ \text { Diana Ross } & 18 & 2 \\ \text { Modern Talking } & 18 & 12 \\ \text { Iron Maiden } & 17 & 11 \\ \text { Madonna } & 17 & 28 \\ \text { Whitesnake } & 17 & 11 \\ \text { The Rolling Stones } & 17 & 10\end{array}$

Taulukko 6. Eniten albumeja myyneet kansainväliset artistit Suomessa vuosina 1980-1989 sekä artistin muisteluaineistossa maininneet vastaajat.

\section{Mitä musiikista muistellaan ja mitä ei?}

Musiikkielämyksiin keskittyviä elämäkertoja tarkastellut Kimmo Jokinen toteaa, että 1960- ja 1970-luvulle sijoittuvissa musiikkimuistoissa korostuvat "kavereiden keskeiset kinastelut siitä, mikä yhtye on paras, konserteissa käynnit, tupakointi- ja alkoholikokeilut, radio-ohjelmat, pukeutuminen, idoleiden jäljittely, 
levysoittimet ja matkat levykauppaan" - elämäkerroissa musiikki on "muistojen kiteyttäjä" (Jokinen 2003: 53). Myös nyt kerätyissä 1980-lukua koskevissa muistoissa toistuu musiikkimuistojen kiinnittyminen sekä lukuisiin eri artisteihin että - kenties vielä vahvemmin - musiikin kuuntelun materiaalisiin ja sosiaalisiin konteksteihin, joista kirjoitetaan hyvin tunnevaltaisesti.

Musiikkiteknologia on muistitietoaineistossa näkyvästi esillä. Ääniteformaatit, C-kasettien nauhoittaminen ja siihen liittyvä tekniikka eri äänitemerkkeineen, levysoittimet ja kasettisoittimet sekä muu äänentoistotekniikka kytkeytyvät saumattomasti musiikin muisteluun. Äänitteiden hankinnasta pyydettiinkin kertomaan jo kirjoituskutsussa: "Mistä sait musiikkia - ostitko, nauhoititko, lainasitko...?" Kerrotut muistot tarjoavat kurkistuksen musiikin materialisoitumiseen arjessa. Esiintyjien, kappaleiden ja albumien maininnat lomittuvat tarinoihin siitä, miten äänitteitä ostettiin levykaupasta tai huoltoasemalta, tilattiin postimyynnistä tai nauhoitettiin radiosta tai ystäviltä tai kirjastosta lainatuilta levyiltä. Vuosikymmenen loppua kohti mukaan tulevat uutena elementtinä musiikkivideot ja videonauhurit. Niiden arkisesta käytöstä kertoo muun muassa tämä kuvaus: "Ja ihana Little Steven. Minä näin hänet jossain musiikkiohjelmassa telkkarissa, kun hän lauloi 'Out of the darkness'. Joku kaverini oli saanut sen nauhoitettua videolle, ja sitä minä jaksoin katsoa kerta toisensa jälkeen." (SK KRA: NK13.)

Musiikin ja äänitteiden muistelu tuo näkyviin sen, miten musiikin saatavuudessa 1980-luvulla alueelliset erot olivat suuret. Kaupungeissa tai niiden läheisyydessä asuneet kertovat ostaneensa äänitteitä levykaupoista, musiikkiliikkeistä tai tavarataloista tai lainanneensa musiikkia kirjastosta. Samanaikaisesti kaupunkien ulkopuolella musiikkivalikoima perustui kenties vielä vahvemmin television ja radion tarjontaan sekä oman sosiaalisen verkoston musiikkimakuun, ja lisäksi postimyynti mainitaan apuna tarjonnan niukkuuteen. Musiikkivideoita koskevissa muistoissa alueelliset erot teknologian saatavuudessa korostuivat, sillä musiikkivideoita maininneet kuuntelijat olivat pääsääntöisesti kaupunkilaisnuoria, joilla oli mahdollisuus nähdä huomattavasti enemmän videoita kaapelitelevision musiikkikanavilta kuin mitä kotimaiset televisiokanavat tarjosivat. Muistelijat ovat varsin tietoisia sekä tarjonnan vähäisyydestä että maan sisäisistä alueellisista eroista. Osa heistä hakee jopa syitä musiikin merkityksellisyydelle juuri tarjonnan vähäisyydestä. 
Musiikkiteknologia on tärkeässä suhteessa myös musiikin kuuntelun paikkoihin. Esimerkiksi autostereot ja samalla auto musiikin kuuntelun kontekstina toistuu aineistoissa useaan otteeseen (vrt. Kilpiö 2011: 50). Muistot niistä voivat kytkeytyä tiettyihin artisteihin - peräti kaksi kirjoittajaa muistelee kuunnelleensa autossa Miljoonasade-yhtyeen kappaletta Marraskuu (sKS KRA: NK12, NK69). Auto toimi omana yksityisenä musiikin kuuntelun tilana, erään kirjoittajan muistoissa ainoana paikkana, jossa musiikkiin saattoi keskittyä omassa rauhassa. Vastaavia kokemuksia muistoissa liitetään 1980-luvulla yleistyneisiin korvalappustereoihin: "Kuljin nuorena ulkona pakkasella, ja annoin Kate Bushin kasetin soida ja ajattelin, että nyt olen yhtä musiikin kanssa" (sKS KRA: NKO4).

Musiikin toistamiseen ja kuunteluun liittyvien teknologioiden yhteys erilaisiin paikkoihin tiivistyy erään kirjoittajan muistelussa:

\footnotetext{
Musiikki oli minulle valtavan tärkeää ja kuuntelin paljon musiikkia: minulla oli kasettisoitin vieressäni kirjoituspöydällä (kuten monilla teini-ikäisillä), walkman ("freestyle" kuten sitä jostain syystä kutsuttiin ruotsiksi), joka oli mukana kävelyillä, matkoilla jne., ja perheelläni oli hyvät stereot, joita käytin pääasiassa minä. (sLs: S13, käännös kirjoittajien)
}

Vaikka teknologisten käyttömahdollisuuksien merkitys musiikin kulutukselle on ilmeinen, niin musiikkimuistoissa teknologialla on aivan oma erityinen funktionsa. Laitteet ja äänitteet toimivat ensisijaisesti muistin paikkoina, kiinnittymispisteinä. Näiden esineiden kautta määritellään, mikä on säilyttämisen ja muistamisen arvoista (vrt. Koskijoki 1997: 269). Esimerkiksi autoa koskevissa muistoissa korostuvat toisaalta oma rauha ja mahdollisuus uppoutua musiikkiin, toisaalta sosiaalinen merkitys paikkana, jossa musiikkia kuunneltiin perheen ja kavereiden kanssa.

Musiikin muistelu onkin usein ihmissuhteiden ja yhteisöjen muistelua ja niiden merkityksellistämistä. 1980-luvun musiikkimuistoissa tähän sosiaaliseen ulottuvuuteen limittyy muistelijoiden artikulaatioita omasta identiteetistä ja sen muutoksista. Nämä muistot eivät aina ole pelkästään positiivisia, vaan niihin voi yhdistyä ikäviä tai hankalia tunteita, jotka osalla muistelijoista vaikuttavat halukkuuteen tai haluttomuuteen kuunnella 1980-luvun musiikkia nykyisin. Lisäksi muistelijat arvottavat 1980-luvun musiikkia eri tavoin: osalle muistelijoista 
"kasarimusiikki" on parempaa kuin nykymusiikki, kun taas osa yhtyy artikkelin alussa esitettyihin käsityksiin sen kaupallisuudesta, pinnallisuudesta ja heikosta laadusta. Omaan aiempaan musiikkimakuun voidaan siis suhtautua huvittuneesti tai häpeilevästi. Musiikin muisteluun kytkeytyvät tunteet voivat olla hyvinkin ristiriitaisia. Tämä herättää osaltaan pohtimaan sitä, mitä 198o-luvun musiikista ei edes haluta muistella ja mitä aineistosta jää siten kenties puuttumaan.

Pilvi Torsti (2012: 64-67) osoitti suomalaisten historiatietoisuutta käsitelleessä tutkimuksessa, kuinka 1980-luvun alussa nuoruuttaan eläneelle kylmän sodan päättymisen sukupolvelle avainasioiksi muodostuivat muun muassa "rauhanliike, tasa-arvo, rasisminvastaisuus, talous ja erityisesti pörssipeli." Monet näistä teemoista löytyvät suoraan sekä aikakauden musiikista että nuorten ja nuorten aikuisten arkikokemuksesta. Silti erityisesti poliittisista teemoista muistelijat eivät maininneet käytännössä mitään. Lähes ainoa poikkeus - ja sekin aiheensa puolesta erityinen - oli vuonna 1985 järjestetty Live Aid -hyväntekeväisyyskonsertti, jota seurattiin televisiosta myös Suomessa. Eräs kirjoittajista muistelee, miten hohdokasta ja hämmästyttävän tuntuista oli "seurata reaaliaikaisesti tapahtumaa, jota koko maailma katsoi" (sKS KRA: NK65).

Aiemmassa tutkimuksessa musiikin uusi aalto 1970-luvun lopussa ja 1980-luvun taitteessa on nähty sukupolvikokemuksena, joka yhdistää tuolloin nuoruuttaan eläneitä ja johon kytkeytyy yhteiskunnallisia teemoja, kuten kulutusvastaisuus ja ympäristön tuhoutuminen (ks. Jokinen 2003, 56). Niin kasaria! -muistelijat eivät kuitenkaan käsittele näitä aiheita, vaikka kirjoituksissa paikoin nousee esiin leimallisesti uuteen aaltoon kuuluneita esiintyjiä, kuten Depeche Mode, Blondie ja The Clash. Mielikuvat 1980-luvun musiikista eivät siis ainakaan näiden kirjoittajien kuvauksissa kytkeydy luontevasti poliittisiin aiheisiin.

\section{Johtopäätökset}

Muistitietoaineiston ja äänitemyyntitilastojen tarkastelu vertailevalla otteella avaa uusia näkökulmia 1980-luvun nuorison musiikkikulttuurien tarkasteluun. Musiikin kulutukselle vuosikymmen edusti muistitiedon valossa lisääntyvän tarjonnan ja eriytyvien musiikkikulttuurien aikaa. Vaikka äänitemyynti ei kerro 
pelkästään nuorten kulutuskohteista, niin sen vertailu muistitietoon paljastaa nimenomaan nuorten musiikkimaiseman moninaisuuden. Myyntilistoilla kaikkein menestyneimmät rock- ja popesiintyjät kyllä vilahtavat tiuhaan muistelukirjoituksissa, mutta yhteisiä suosikkeja nousee esiin vain vähän. Ainoastaan Dingoyhtyettä muistellaan ahkerasti, peräti kolmanneksessa muistitietokirjoituksista, ja vieläpä hyvin monisanaisesti: yhtyeen kohdalla kyse onkin poikkeuksellisesta, musiikin kulutuksen ulkopuolelle ulottuvasta kulttuurisesta ilmiöstä, jota medianostalgia on osaltaan vahvistanut.

Aikakautta muisteleville merkityksellisen musiikin valikoima on myyntilistojen kertomaa laajempi: lähes jokainen yksittäinen muistelija mainitsee lukuisia laulajia ja yhtyeitä niin Suomesta kuin ulkomailta. Mainitut artistit eivät useinkaan olleet suuria menestysnimiä. Lisäksi muistoissa tuodaan esille jo ennen 1980-lukua julkaistua musiikkia, mikä osaltaan vahvistaa äänitemyyntilistojen rajallisuutta musiikin kulutuksen ja musiikkikulttuurien tutkimuksessa. 1980-luvulla nuoruuttaan eläneet muistelevat siis myös sellaista musiikkia, joka on unohtunut julkisessa nostalgisoinnissa.

Alueelliset erot suomalaisten musiikin kulutuksessa näyttäytyvät muistitietoaineistossa käytänteiden kirjona. Musiikin saatavuus vaikutti musiikin kulutukseen ja kuunteluun eri tavoin eri puolilla maata. Erityisen kiinnostava maantieteellinen ja kieleen liittyvä ero paljastuu ruotsinkielisten ja suomenkielisten muistelijoiden musiikkimaisemia vertailemalla: Ruotsin median vaikutteet muokkasivat Suomen länsirannikolla asuvien ruotsinkielisten nuorten musiikkimaisemaa selvästi omaan suuntaansa. Vastaavaa tarkastelua olisi hedelmällistä tehdä myös muiden maantieteellisten alueiden osalta ja muita aineistoja hyödyntämällä.

Eri aineistojen vertailu paljastaa myös sen, että 1980-luvun musiikki ei vaikuta pelkästään tuolloin nuoruuttaan eläneiden muistoissa. Lähes kaikki ahkerasti mainitut 1980-luvun artistit ovat olleet aktiivisia vielä 2000-luvulla, suuri osa myös Niin kasaria! -muistelukeruun järjestämisen aikaan vuonna 2015.

Aineiston perusteella musiikkimuistot kytkeytyvät vain harvoin yksittäisiin musiikkikappaleisiin tai julkaistuihin äänitteisiin. Ainakaan niistä ei suuremmin kirjoiteta. Sen sijaan musiikin kulutukseen liittyvät esineet, käytänteet, paikat ja ihmiset ovat muistojen keskiössä. Näiden kautta myös erilaiset musiikkiin liittyvät tunteet ovat läsnä muistelukerronnassa. Musiikkimuistot kytkeytyvätkin 
ennen kaikkea henkilökohtaiseen kokemukseen ja elämänhistoriaan. Poliittiset ja yhteiskunnalliset aiheet puuttuvat musiikkimuistoista lähes kokonaan.

Jatkotutkimuksessa onkin syytä paneutua entistä tarkemmin siihen, mitä musiikista ei muistella ja miksi. Yksi vaihtoehto on musiikkimuistojen vertailu radion soittolistoihin ja toisaalta laajemmin mediassa esillä olleeseen musiikkiin. Muistitietoaineisto antaa myös tilaisuuden tarkastella kulttuurista makua ja sen muutoksia eli sitä, millaisia makuyhdistelmiä ja erontekoja aineistosta on löydettävissä toisaalta muisteltavassa ajassa ja toisaalta nykyajan ja menneisyyden välillä ja miten näitä erontekoja rakennetaan. Kokonaiskuvan muodostaminen 1980-luvun nuorten musiikkikulttuureista tuleekin edellyttämään juuri erilaisten, toisistaan selvästi poikkeavien aineistojen ja menetelmien yhdistämistä.

\section{Lähteet}

\section{Tutkimusaineisto}

\section{Arkistolähteet}

Kansanrunousarkisto (KRA), Suomalaisen Kirjallisuuden Seura (SKR), Helsinki.

Niin kasaria! -kyselykeruu (NK), 2015. https:/ / www.finlit.fi/fi/niin-kasaria

Svenska Litteratursällskapet i Finland (sLs), Helsingfors.

Så 8o-tal! -insamling (S), 2015. http:/ / www.sls.fi/sv/projekt/insamling-sa-198o-tal

\section{Painetut lähteet}

Nyman, Jake (toim.) (2005) Suomi soi 4: Suuri suomalainen listakirja. Helsinki: Tammi.

Pennanen, Timo (2006) Sisältää hitin: Levyt ja esittäjät Suomen musiikkilistoilla vuodesta 1972.

Helsinki: Otava.

Rantanen, Ilpo (2002) Vuonna 85: Manserockin lyhyt oppimäärä. Helsinki: Siltala.

Sirén, Vesa (2017) Tää menee näin. Vuoden biisit 1977-2017. Valokuvat Juha Metso. Helsinki: Like. Sivonen, Henna-Kaisa (2009) Kasarikirja. Jyväskylä: Atena. 


\section{Tutkimuskirjallisuus}

Abrams, Lynn (2010) Oral History Theory. Milton Park \& New York: Routledge.

Ampuja, Outi, Järviluoma, Helmi, Kilpiö, Kaarina \& Uimonen, Heikki (2005) “Muuttuva äänimaisema - johdatus tutkimukseen". Kuultava menneisyys. Suomalaista äänimaiseman historiaa. Toim. Outi Ampuja ja Kaarina Kilpiö. Historia mirabilis 3. Turku: Turun historiallinen yhdistys.

Ampuja, Outi \& Peltomaa, Miikka (toim.) (2014) Huutoja hiljaisuuteen. Ihminen ääniympäristössä. Helsinki: Gaudeamus.

Doggett, Peter (2007) There's a Riot Going on: Revolutionaries, Rock Stars and the Rise and Fall of 1960 Counter Culture. Edinburgh: Canongate.

Fingerroos, Outi \& Haanpää, Riina (2006) "Muistitietotutkimuksen ydinkysymyksiä". Muistitietotutkimus. Metodologisia kysymyksiä. Toim. Outi Fingerroos, Riina Haanpää, Anne Heimo \& Ulla-Maija Peltonen. Tietolipas 214. Helsinki: Suomalaisen Kirjallisuuden Seura, $25-48$.

Frith, Simon (1988 [1983]) Rockin potku. Nuorisokulttuuri ja musiikkiteollisuus. Suomen etnomusikologisen seuran julkaisuja 1. Suom. Hannu Tolvanen. Tampere: Osuuskunta Vastapaino 1988 (alkuteos: Sound effects. Youth, leisure, and the politics of rock. London: Constable).

Gronow, Pekka \& Lindfors, Jukka \& Nyman, Jake (toim.) (2004) Suomi soi: 2. Rautalangasta hiphoppiin. Helsinki: Tammi.

van der Hoeven, Arno (2014) "Remembering the popular music of the 1990s: dance music and the cultural meanings of decade-based nostalgia". International Journal of Heritage Studies 20:3, 316-330.

Jokinen, Kimmo (2003) "Kirjoitetut rockmuistot. Musiikki muistina". Hyoää pahaa rock 'n' roll. Sosiologisia kirjoituksia rockista ja rockkulttuurista. Toim. Kimmo Saaristo. Tietolipas 194. Suomalaisen Kirjallisuuden Seura. Jyväskylä: Gummerus, 40-61.

Kallioniemi, Kari (2006) Blitzistä blairismiin. Englantilainen populaarikulttuuri ja yhteiskunta toisen maailmansodan jälkeen. Turku: $\mathrm{k} \& \mathrm{~h}$.

Kallioniemi, Kari, Kärki, Kimi \& Mähkä, Rami (2016) "Kekkonen ja rock'n'roll". Maamme. Itsenäisen Suomen kulttuurihistoria. Toim. Marjo Kaartinen, Hannu Salmi \& Marja Tuominen. Kirjokansi 109. Helsinki: Suomalaisen Kirjallisuuden Seura.

Kemppainen, Pentti (2001) Radion murros. Julkisradioiden kanavauudistus Norjassa, Ruotsissa ja Suomessa. Helsinki: Helsingin yliopisto. 
Kemppainen, Pentti (2011) Aina soi sävelradio. Radiomusiikista musiikkiradioon. Vantaa: Avain.

Kilpiö, Kaarina (2011) "C-kasetit suomalaisten käyttäjiensä aistimuistoissa". Tekniikan Waiheita 4/2011, 39-54.

Kilpiö, Kaarina, Kurkela, Vesa \& Uimonen, Heikki (2015) Koko kansan kasetti. C-Kasetin käyttö ja kuuntelu Suomessa. Suomalaisen Kirjallisuuden Seuran Toimituksia 1413. Helsinki: Suomalaisen Kirjallisuuden Seura.

Koskijoki, Maria (1997) "Esine muiston astiana". Aina uusi muisto. Toim. Katariina Eskola \& Eeva Peltonen. Nykykulttuurin tutkimusyksikön julkaisuja 54. Jyväskylä: Jyväskylän yliopisto, 269-288.

Kurkela, Vesa (2003) "Eriytyvien yleisöjen aika: Vuodet 1963-90". Suomen musiikin historia: Populaarimusiikki. Toim. Pekka Jalkanen \& Vesa Kurkela. Helsinki: wsoy.

Laing, Dave (2015 [1985]) One Chord Wonders. Power and Meaning in Punk Rock. Oakland: PM Press.

Lassila, Juha (1990) Mitä Suomi soittaa? Hittilistat 1954-87. Nykykulttuurin tutkimusyksikön julkaisuja 20. Jyväskylä: Jyväskylän yliopisto.

Lähteenmaa, Jaana (1992) "Miten käy tytöiltä rock'n roll". Letit liehumaan. Toim. Sari Näre \& Jaana Lähteenmaa. Helsinki: Suomalaisen Kirjallisuuden Seura, 211-222.

Mauch, Matthias, MacCallumn, Robert M., Levy, Mark \& Leroi, Armand M. (2015) “The evolution of popular music: USA 1960-2010". Royal Society Open Science 2:5. Royal Society Open Science 2:5. http:/ / rsos.royalsocietypublishing.org/content/2/5/150081

Muikku, Jari (2001) Musiikkia kaikkiruokaisille. Suomalaisen populaarimusiikin äänitetuotanto 19451990. Helsinki: Gaudeamus.

Poiger, Uta G. (1996) “Rock'n Roll, Female Sexuality and the Cold War Battle over German Identities". Journal of Modern History 68: 3, 577-616.

Poikolainen, Janne (2015) Musiikkifanius ja modernisoituva nuoruus. Populaarimusiikin ihailijakulttuurin rakentuminen Suomessa 1950-luvulta 1970-luvun alkuun.

Nuorisotutkimusverkosto/Nuorisotutkimusseura, Julkaisuja 168, Tiede. Helsinki: Nuorisotutkimusseura.

Pöysä, Jyrki (2006) “Kilpakirjoitukset muistitietotutkimuksessa”. Muistitietotutkimus. Metodologisia kysymyksiä. Toim. Outi Fingerroos, Riina Haanpää, Anne Heimo \& Ulla-Maija Peltonen. Tietolipas 214. Helsinki: Suomalaisen Kirjallisuuden Seura, 221-224.

Pöysä, Jyrki (2015) Lähiluvun tieto. Näkökulmia kirjoitetun muistelukerronnan tutkimukseen. Joensuu: Suomen Kansantietouden Tutkijain Seura. 
Ryback, Timothy W. (1990) Rock around the Bloc: A History of Rock Music in Eastern Europe and the Soviet Union. New York: Oxford University Press.

Salokangas, Raimo (1996) Yleisradion Historia: 2. osa, 1949-1996. Aikansa oloinen. [Helsinki]: Yle.

Skaniakos, Terhi (2010) Discoursing Finnish rock: Articulations of identities in the Saimaa-ilmiö rock documentary. Väitöskirja. Jyväskylä studies in humanities 140. Jyväskylä: University of Jyväskylä. http:/ / urn.fi/URN:ISBN:978-951-39-3887-1

Söderholm, Stig, Knuuttila, Seppo, Katajala, Kimmo \& Kupiainen, Jari (1987) Näkökulmia rockkulttuuriin. Helsinki: Otava.

Thornton, Sarah (1996 [1995]) Club Cultures. Music, media and subcultural capital. Hanover \& London: University Press of New England.

Torsti, Pilvi (2012) Suomalaiset ja historia. Gaudeamus: Tampere.

Töykkälä, Esa \& Uusitupa, Timo (1987) Paikallisradioiden ohjelmisto. Paikallisradiokokeilun seurantatutkimus. Liikenneministeriön julkaisuja 1/1987. Liikenneministeriö, Tampereen yliopisto: Tampere.

Uimonen, Heikki (2011) Radiomusiikin radiomuutos. Kaupallisten radiokanavien musiikki 1985-2005. Tampere: Tampere University Press.

Uimonen, Heikki (2012) “Inarin emäntäkoulussa. C-kasetti jokapaikkaisen kuuntelun edistäjänä". Etnomusikologian vuosikirja Vol. 24, 97-119. https://doi.org/10.23985/evk.66813

Uimonen, Heikki, Kytö, Meri \& Ruohonen, Kaisa toim. (2017) Muuttuvat suomalaiset äänimaisemat. Tampere: Tampereen yliopistohttp:/ / urn.fi/URN:ISBN:978-952-03-0382-2

Wertsch, James V. (2002) Voices of Collective Remembering. Cambridge: Cambridge University Press.

Zhuk, Sergei I. (2010) Rock and Roll in the Rocket City: The West, Identity and Ideology in Soviet Dniepropetrovsk, 1960-1985. Washington, DC: Woodrow Wilson Center Press; Baltimore: Johns Hopkins University Press. 